\title{
ECOLOGY OF ARBOVIRUSES IN SRI LANKA: A SUMMARY OF STUDIES FROM $1984-1990$
}

\author{
J.S.M. Peiris ${ }^{1}$, C.K. Arunagiri ${ }^{2}$ and L.P. Perera ${ }^{3}$ \\ ${ }^{1}$ Department of Microbiology, Queen Mary Hospital, University of Hong Kong, Pokfulam Rd, \\ Hong Kong SAR. \\ ${ }^{2}$ Veterinary Officer, AQIS, 42-44 Qantas Drive, Eagle Farm, QLD 4009, Australia. \\ ${ }^{3}$ Center for Cancer Research, National Cancer Institute, Bldg. 10, Bethesda, MD 20892-1374, USA. \\ Accepted 10 June 2008
}

\begin{abstract}
Studies on arboviruses carried out between 1984 -1990 at the University of Peradeniya are summarized here. The isolation of Nairobi sheep disease virus, Getah, Batai and Arkonam and serological evidence of the circulation of California encephalitis serogroup and Chandipura viruses have been reported for the first time in Sri Lanka. The ecology of Japanese encephalitis (JE) in areas with epidemic disease and sylvatic infection has been compared. A synchronous pattern of seroconversion in pigs and seroprevalence in cattle are more predictive of epidemic JE risk than overall porcine seroprevalence which is a good indicator of the presence of sylvatic JE rather than of human epidemic risk. Relatively modest changes in vector abundance associated with rainfall or agricultural practices have dramatic changes on the emergence of epidemic JE. Chandipura virus which is known to cause major outbreaks of encephalitis in India is endemic in Sri Lanka as are viruses belonging to the California encephalitis serogroup. Both these viruses are potential causes of human encephalitis and should be sought in patients with undiagnosed encephalitis. Nairobi sheep disease virus is endemic in animals (especially goats) and infects humans working closely with such livestock. Arboviruses remain an under-recognised cause of human and animal disease and an inter-sectoral multidisciplinary approach is needed to confront such emerging infectious disease threat.
\end{abstract}

Keywords: Japanese encephalitis, California serogroup, Alphavirus, mosquito, Chandipura virus

\section{INTRODUCTION}

Arboviruses (derived from arthropod-borne viruses) are a group of taxonomically diverse viruses that share a common mode of transmission between vertebrate hosts. The arthropods responsible for the transmission of these viruses are usually mosquitoes, ticks, sand flies, or less often, other insects. The majority of them fall into the taxonomic groups of the Togaviridae (Alphaviruses), Flaviviridae and Bunyaviridae. Most arboviruses (dengue and chikungunya being exceptions) are maintained in animal reservoirs with human infection being a tangential event, if at all, without much consequence to the survival of the virus. However, such infections can have significant implications for public health. Dengue continues to wreak havoc in many parts of Asia, Africa and South America (Messer et al., 2002) while Japanese encephalitis (JE) remains a major cause of death and disability in Asia (Mackenzie et al., 2002). West Nile virus has crossed the Atlantic to entrench itself in North America. Most intriguing of all, Chikungunya virus has re-emerged after a "silence" of 40 years to become a major public health threat in many Asian countries and beyond (Powers and Logue, 2007).

A multi-disciplinary collaborative research program was initiated in 1983 by the late Prashantha Amerasinghe (Department of Zoology), Manel de S Wijesundera (Department of Parasitology) and J.S.M. Peiris (Department of Microbiology) at the University of Peradeniya to better understand the impact of ecological change on mosquito vectors of disease (Amerasinghe and Munasinghe ,1988; Amerasinghe et al., 1991; Amerasinghe et al., 1994) and to study the ecology of arboviruses in Sri Lanka. While some of the data on ecology of arboviruses has been published, other aspects of this work are so far only documented in M. Phil. and Ph.D. theses at the University of Peradeniya (Perera, 1986; Arunagiri,.1990). It is therefore opportune to summarize the findings of this research program on the ecology of arboviruses in Sri Lanka, particularly since some of these findings have

*Corresponding author's email: malik@hkucc.hku.hk 
increased in potential clinical relevance in the last decade. These studies have included a) Virus isolation from live caught mosquitoes and ticks, b) sero-epidemiological studies using neutralization tests and c) studies on the ecology and epidemiology of Japanese encephalitis virus in different regions of Sri Lanka.

\section{Virus isolation from mosquitoes and ticks}

Virus isolation was attempted from 178,181 un-engorged female mosquitoes collected between 1984-89 in the Anuradhapura (Dry zone), Dehiattakandiya (Intermediate zone area undergoing rapid ecological change as part of the Mahaweli System C irrigation program) and Kandy (Wet zone) areas (Peiris et al., 1992; Peiris et al., 1994). The viruses isolated are summarized in Table 1. Isolates of JE virus were obtained from different mosquito species and have helped define the mosquito species that transmit the virus in an epidemic setting. These studies also provided the first record of isolation of alphavirus Getah in the Indian subcontinent; the Bunyavirus Batai and the reovirus Arkonam from mosquitoes in Sri Lanka (Peiris et al., 1994) and Nairobi sheep disease (NSD) virus from pools of Haemaphysalis intermedia ticks (Perera et al., 1996) (Table 1).

\section{Japanese encephalitis}

Japanese encephalitis was endemic in Sri Lanka for decades (Hermon and Anandarajah, 1974; Vesenjak-Hirjan et al., 1969) but the first major epidemic occurred in 1985 in the Anuradhapura district, North Central Province. There were substantial epidemics of varying magnitude in the subsequent years. From 1987 1989, a prospective study of human disease, porcine seroconversion, vector abundance and virus carriage in mosquitoes was carried out in the Anuradhapura district. Based on JE specific IgM detection ELISA, 361 cases were virologically confirmed as JE between November 1987 and January 1988. Virus isolation incriminated the classical JE mosquito vectors Culex tritaeniorhynchus, Culex gelidus and Culex fuscocephala as vectors. These virus isolations were temporally correlated with porcine seroconversion and human disease (Peiris et al., 1992). JE virus was also found in Culex whitmorei by virus isolation and in Mansonia uniformis by antigen detection ELISA (Peiris et al., 1992; Peiris, 1994) but the overall vector abundance of these species was low and the role they played in the overall transmission of the virus is less clear. The vector responsible for the maintenance of the virus in its sylvan reservoir was not identified in these studies where mosquito trapping was done using light traps near pig pens. However, the isolation of JE virus from Culex tritaeniorhynchus and Mansonia uniformis in the forested / early settlement phase of the Mahaweli System C program at Dehiattakandiya and from Culex pseudovishnui in Kandy where there was no epidemic JE activity suggested that these species may be the responsible for the sylvatic transmission cycle. Both these species were found in substantial numbers (as many as 0.68 and 0.45 females / hr respectively) in the human biting collections in the forests of the Dry zone during the monsoon period (Amerasinghe and Munasinghe, 1988).

Table 1. Virus isolations from wild-caught female mosquitoes. (Tested in pools of up to 200 each)

\begin{tabular}{|c|c|c|c|}
\hline Location & Viruses & Mosquito species (pools positive) & MIR*/1000 females \\
\hline $\begin{array}{l}\text { Anuradhapura } \\
1986-89 \\
\mathrm{n}=59,422\end{array}$ & $\begin{array}{l}\text { Japanese encephalitis } \\
\text { Getah } \\
\text { Arkonam }\end{array}$ & $\begin{array}{l}\text { Culex tritaeniorhynchus (4) } \\
\text { Culex gelidus }(5) \\
\text { Culex tritaeniorhynchus }(6) \\
\text { Culex gelidus }(1) \\
\text { Culex gelidus }(1)\end{array}$ & $\begin{array}{l}0.15 \\
0.2 \\
0.23 \\
0.04 \\
0.04\end{array}$ \\
\hline $\begin{array}{l}\text { Dehiattakandiya } \\
1985-89 \\
\mathrm{n}=62,079\end{array}$ & $\begin{array}{l}\text { Japanese encephalitis } \\
\text { Arkonam }\end{array}$ & $\begin{array}{l}\text { Culex tritaeniorhynchus (3) } \\
\text { Mansonia uniformis (2) } \\
\text { Culex fuscocephala (1) }\end{array}$ & $\begin{array}{l}0.11 \\
>1 \\
0.13\end{array}$ \\
\hline $\begin{array}{l}\text { Kandy } \\
1984-87 \\
n=56,680\end{array}$ & $\begin{array}{l}\text { Japanese encephalitis } \\
\text { Getah }\end{array}$ & $\begin{array}{l}\text { Culex pseudovishnui (1) } \\
\text { Culex tritaeniorhynchus (1) }\end{array}$ & $\begin{array}{l}0.16 \\
0.09\end{array}$ \\
\hline & Batai & $\begin{array}{l}\text { Culex fuscocephala (1) } \\
\text { Anopheles vagus (1) }\end{array}$ & $\begin{array}{l}0.06 \\
0.19\end{array}$ \\
\hline
\end{tabular}

* MIR=Minimum infection rates / 1000 female mosquitoes tested. 
Interestingly, we found evidence of JE seropositivity in persons engaged in slash and burn cultivation in the Dry zone forests (Perera, 1986). Ardeid water birds (e.g. Bubulcus ibis, Ardeola greyii) are the likely sylvatic reservoir hosts of JE and Culex pseudovishnui is likely to feed on such birds as well as on pigs and cattle and may potentially be the bridging vector between the sylvatic reservoir and the porcine amplifier host. The JE viruses isolated from Cx.pseudovishnui in Kandy and from a patient with JE encephalitis in Anuradhapura have been genetically sequenced and found to be closely related suggesting that the lack of epidemic JE in Kandy is not due to differences in virus virulence (Chen et al., 1990) but is more likely due to abundance of vectors and amplifier hosts.

Porcine seroconversion followed a biphasic pattern, a slowly progressive phase of infection occurring through October 1987 when approximately $25 \%$ of the animals got infected, followed by a sharp synchronous burst of infection when the remaining animals got infected within a two week period in early November 1987. The human epidemic curve followed this burst of porcine seroconversion with a lag of 2-4 weeks and all ages of humans were equally affected, indicating an outbreak in an immunologically naive population. These findings confirmed the role played by pigs as an amplifier of the virus. Indeed it was highly likely that the reason why epidemic JE suddenly emerged in Anuradhapura, an ecologically stable rice growing region in 1985, was the introduction of small-holder pig-husbandry in the preceding few years to this ecosystem with high JE vector abundance because of intensive synchronized irrigated rice cultivation. The lessons learnt from this experience averted a similar mistake being repeated in the Mahaweli System C areas which were being developed for irrigated agriculture in the subsequent years.

Interestingly, there were few human cases in the subsequent year, i.e. 1988/9, viz. 11 confirmed cases in comparison to 361 cases in the preceding year. Thus, the difference of human disease burden in the two years was remarkable. This was not explained by build up of herdimmunity in the population since only $20 \%$ of the population had JE neutralizing antibody in early 1988. A vaccination campaign targeted at young children could not explain the marked reduction of disease in all ages. The notable difference in the two years was a roughly 5-fold reduction in the abundance of the major JE vectors, $C x$ tritaeniorhynchus and $C x$ gelidus (Peiris et al.,
1992). The change in vector abundance was attributable to changes in rainfall patterns in the two years and perhaps also to the disorganization of the irrigation water releases in the area due to the civil unrest that prevailed in the area. The correlation of rainfall pattern and JE disease deserves further study.

Interestingly, the change in vector abundance was associated with a subtle change in the profile of porcine seroconversion. While the overall porcine seroprevalence reached almost $100 \%$ in both years, in 1998 (low human JE year) there was an absence of the sharp synchronous burst of porcine seroconversion observed in 1987. This suggested that it was not the overall porcine seroprevalence that predicted high JE risk but rather the tightly synchronized seroconversion in pigs. These hypotheses were confirmed by ecological studies of JE in different agroclimatological regions of Sri Lanka. Porcine seroprevalence did not correlate with risk of human JE; for example Kandy had a cumulative or cross sectional porcine seroprevalence not dissimilar to that of Anuradhapura. What did differ was the lack of synchronized seroconversion over a short period of time. Indeed, our studies suggested that bovine seroprevalence correlated better with human epidemic JE risk than does porcine seroprevalence (summarized in Table 2), probably because bovines were a spillover host for JE virus just as humans are. On the other hand, cross sectional porcine seroprevalence is a very sensitive indication of $\mathrm{JE}$ virus activity in the sylvatic reservoir but not necessarily a predictor of human spillover infection (Peiris et al., 1993a).

\section{Dengue viruses}

Uncomplicated dengue fever was endemic in Sri Lanka for decades (Maheswaran et al., 1976) but the emergence of dengue haemorrhagic fever as a major public health threat in Sri Lanka was a more recent phenomenon (since 1989) and occurred subsequent to the period covered by the studies reported here. As dengue was not a particular focus of our studies the mosquito collection methods were not targeted the classical dengue vectors Aedes egypti and Aedes albopictus. Seroprevalence (neutralizing antibody) to dengue 2 virus in humans in Kandy, Anuradhapura and in prior settlers involved in slash and burn agriculture in the Maduru Oya forested environment was $16 \%, 25 \%$ and $21 \%$ respectively, indicating that dengue was widespread in the island even pre-1988 although dengue haemorrhagic fever was then uncommon (Perera,1986). 
Interestingly, a seroepidemiological study of torque macaques (Macaca sinica) in Polonnaruwa in 1987 revealed evidence of high (94\%) seroprevalence to dengue 2 (but not to JE virus) (Peiris et al., 1993b). A follow-up study conducted in 1995 by De Silva et al., (1999) confirmed that the dengue epizootic was limited in both space and time, indicting that this was most likely a spill over of infection from humans to macaques rather than a result of endemic virus transmission within this ecosystem

\section{Alphaviruses: Getah and chikungunya}

In agreement with studies in Malaysia, we found Cx tritaeniorhynchus to be the likely vector of Getah in Sri Lanka. Sero-epidemiological studies using micro-neutralization tests using one of these isolates (An-432) showed that pigs had the highest sero-prevalence while cattle, goats, sheep, dogs, chickens and ducks also have evidence of infection. Human sero-prevalence was low $(0.6 \%)$ in most parts of the country (Table 3) (Arunagiri, 1990). Chikungunya virus is a related alphavirus that caused major disease outbreaks in Sri Lanka in the 1960's (Hermon,
1967). There was no detectable antibody in sera from 321 children aged 5-15 and very low seroprevalence $(1 / 180)$ in adults. This single seropositive serum specimen had low neutralizing antibody titre to chikungunya (1/40) and Sindbis $(1 / 20)$. Overall the studies confirmed that chikungunya was not endemic in Sri Lanka in the last decades and indicated that the population was largely susceptible to the Chikungunya virus and also to other alphaviruses (Table 4) (Arunagiri, 1990). This is relevant as baseline information in view of the major outbreaks of chikungunya fever that have erupted in Sri Lanka, India and other parts of Asia in recent years (Powers et al., 2007).

\section{Batai and Arkonam virus}

The bunyamwera serogroup virus Batai was found to be endemic in Sri Lanka by both virus isolation and by sero-epidemiological studies (Peiris et al., 1994; Arunagiri, 1990). Antibody to Batai virus was common (20-30\%) in cattle, sheep and goats but human seroprevalence was low(Arunagiri,1990).

Table 2. Correlation of Human Japanese Encephalitis Case Notifications with Serological and Entomological Parameters. (Source: Peiris, 1996)

\begin{tabular}{|c|c|c|c|c|}
\hline & Anuradhapura & $\underline{\text { Ragama }}$ & $\underline{\text { Kandy }}$ & $\begin{array}{l}\text { High elevation } \\
\text { / Wet zone }\end{array}$ \\
\hline Elevation $(\mathrm{m})$ & 150 & 30 & 530 & $1270-2070$ \\
\hline JE case notifications / 100,000 (1990) & 26 & $4-72$ & 0.1 & 0 \\
\hline Human JE sero-prevalence (school age) & $17 \%$ & $28 \%$ & $3 \%$ & $2 \%$ \\
\hline Porcine JE sero-prevalence (>13 months) & $89 \%$ & $71 \%$ & $76 \%$ & $17 \%$ \\
\hline Pattern of porcine sero-conversion & Synchronous & Synchronous & Asynchronous & Asynchronous \\
\hline Cattle JE sero-prevalence & $45 \%$ & $71 \%$ & $4 \%$ & $0 \%$ \\
\hline \multicolumn{5}{|l|}{ Mosquito abundance(per trap night) } \\
\hline Cx. tritaeniorhynchus & 898 & 28 & 49 & 1.3 \\
\hline Cx. gelidus & 433 & 96 & 37 & 3.2 \\
\hline Cx. fuscocephala & 77 & 10 & 65 & 9.8 \\
\hline
\end{tabular}

Table 3. Seroprevalence of neutralizing antibody to Getah virus (An432). (Source: Arunagiri, 1990)

\begin{tabular}{lllllll}
\hline $\begin{array}{l}\text { Agro-climatic } \\
\text { zone }\end{array}$ & $\begin{array}{c}\text { Human } \\
(5-15 \mathrm{yr})\end{array}$ & Pigs & Cattle & Goat & Dog & Chicken \\
\hline Dry Zone & $0 / 152$ & $75 / 181$ & $13 / 75$ & $12 / 151$ & $2 / 16$ & $8 / 93$ \\
(NCP) & $(0 \%)$ & $41 \%$ & $17 \%)$ & $(8 \%)$ & $(13 \%)$ & $(9 \%)$ \\
Dry Zone & $1 / 142$ & $5 / 13$ & $2 / 18$ & ND & ND & ND \\
(MSC) & $(1 \%)$ & $38 \%$ & $(11 \%)$ & & & ND \\
Wet Zone & ND & $17 / 228$ & $8 / 35$ & $2 / 37$ & ND & \\
$<1000 \mathrm{ft}$ & & $(7 \%)$ & $(23 \%)$ & $(5 \%)$ & & $0 / 28$ \\
Wet Zone & $2 / 229$ & $2 / 161$ & $22 / 136$ & $4 / 62$ & $0 / 12$ & $(0 \%)$ \\
$1000-3000 \mathrm{ft}$ & $(1 \%)$ & $(1 \%)$ & $(16 \%)$ & $(6 \%)$ & $(0 \%)$ & ND \\
Wet Zone & $0 / 179$ & $24 / 338$ & $0 / 23$ & ND & ND & \\
$>3000 \mathrm{ft}$ & $(0 \%)$ & $(7 \%)$ & $(0 \%)$ & & & \\
\hline
\end{tabular}

Abbreviations: $\mathrm{NCP}=$ North Central Province; $\mathrm{MSC}=$ Mahaweli System $\mathrm{C} ; \mathrm{ND}=$ Not done 
Arkonam is an Orbivirus within the family Reoviridae. It has been previously detected in India but its importance in relation to human or animal disease was unknown. While no seroprevalence studies were done in Sri Lanka so far, studies in India suggest that human infection is not uncommon (Dandawate and Shope, 1975).

\section{Nairobi sheep disease virus}

Nairobi sheep disease (NSD) virus was isolated from pools of Haemaphysalis intermedia ticks collected from the goat breeding station at Kotukachchiya in the North Western Province of Sri Lanka (Perera et al., 1996). This was the first record of its isolation in Sri Lanka although Ganjam virus which is now recognized to be indistinguishable from NSD virus has been isolated from sheep in association with febrile and sometimes fatal illness in India with symptoms similar to those of NSD in East Africa (Ghalsasi et al., 1981). Seroepidemiological studies indicated that human and goat exposure is not uncommon on the farm we studied. Its relation to human and goat disease deserves further investigation.

\section{California serogroup viruses}

Sero-epidemiological studies revealed the activity of a number of other arboviruses in Sri
Lanka. The most important of these was the conclusive documentation of the presence of California serogroup Bunyaviruses and Chandipura virus for the first time in Sri Lanka. Bardos and colleagues had previously reported inconclusive evidence of antibody to Tahyna virus in the animal sera from Sri Lanka (Bardos et al., 1983). Both California serogroup and Chandipura viruses are known causes of viral encephalitis in humans. Neutralization tests revealed the presence of a virus closely related to Snowshoe hare virus and another related to Melao virus (Arunagiri et al., 1991). In a comparative study of sera from school age children (8-16 years) in different agroclimatological regions of Sri Lanka, the highest sero-prevalence $(6 \%)$ in children being found in those living within the dry zone forested areas of the country with $1 \%$ seroprevalence in children elsewhere. Pigs, cattle, dogs, rodents and chicken had significant sero-prevalence to these viruses (Arunagiri et al., 1991). Toque macaques (Macaca sinica) in a sylvatic habitat in the North Central Province of Sri Lanka had high seroprevalence to California serogroup viruses, with an age depended increase in seroprevalence suggesting endemic virus transmission (Peiris et al., 1993).

Table 4. Seroprevalence of neutralizing antibody to Chikungunya and Sindbis viruses. (Source: Arunagiri, 1990)

\begin{tabular}{lll}
\hline & Chikungunya & Sindbis \\
\hline Adult sera & $1 / 180(0.6 \%)$ & $1 / 298(0.34 \%)$ \\
Children (5-15 years) & $0 / 321(0 \%)$ & $1 / 485(0.2 \%)$ \\
\hline
\end{tabular}

Sera collected from different agro-climatic regions of Sri Lanka (see Table 2). There was no obvious difference in seroprevalence when stratified by geographical region.

Table 5. Seroprevalence of neutralizing antibody to Chandipura virus. (Source: Arunagiri, 1990)

\begin{tabular}{lllll}
\hline Agro-climatic zone & Human $(5-15 \mathrm{yr})$ & \multicolumn{1}{c}{ Pigs } & \multicolumn{1}{c}{ Cattle } & \multicolumn{1}{c}{ Goat } \\
\hline Dry Zone (NCP) & $1 / 103(1 \%)$ & $17 / 137(12 \%)$ & $27 / 75(36 \%)$ & $8 / 105(7.6 \%)$ \\
Dry Zone (MSC) & $8 / 142(5.6 \%)$ & $3 / 7(42 \%)$ & $17 / 18(94 \%)$ & ND \\
Wet Zone $<1000 \mathrm{ft}$ & $\mathrm{ND}$ & $3 / 101(3 \%)$ & $18 / 32(56 \%)$ & $2 / 34(5.9 \%)$ \\
Wet Zone $1000-3000 \mathrm{ft}$ & $2 / 229(0.9 \%)$ & $4 / 114(3.5 \%)$ & $57 / 136(42 \%)$ & $4 / 62(6.5 \%)$ \\
Wet Zone $>3000 \mathrm{ft}$ & $3 / 177(1.7 \%)$ & $4 / 159(2.5 \%)$ & $5 / 23(22 \%)$ & ND \\
\hline
\end{tabular}

Abbreviations: $\mathrm{NCP}=$ North Central Province; $\mathrm{MSC}=$ Mahaweli System $\mathrm{C} ; \mathrm{ND}=$ Not done 
Table 6. Arboviruses documented in Sri Lanka.

\begin{tabular}{|c|c|c|c|c|c|c|}
\hline & & & & & \multicolumn{2}{|c|}{$\begin{array}{l}\text { Human disease } \\
\text { world-wide }\end{array}$} \\
\hline Virus & $\begin{array}{c}\text { Isolated } \\
\text { from } \\
\text { humans in } \\
\text { Sri Lanka }\end{array}$ & $\begin{array}{c}\text { Human } \\
\text { sero-positivity } \\
\text { in Sri Lanka }\end{array}$ & $\begin{array}{c}\text { Animal } \\
\text { sero-positivity } \\
\text { in Sri Lanka }\end{array}$ & $\begin{array}{l}\text { Virus isolated } \\
\text { from vector } \\
\text { in Sri Lanka }\end{array}$ & $\begin{array}{l}\text { Human } \\
\text { disease }\end{array}$ & $\begin{array}{c}\text { CNS } \\
\text { disease }\end{array}$ \\
\hline $\begin{array}{l}\text { Japanese } \\
\text { encephalitis }\end{array}$ & + & + & + & $+{ }^{1}$ & $+(\mathrm{SL})^{3}$ & $+(\mathrm{SL})$ \\
\hline $\begin{array}{l}\text { Dengue } \\
\text { types 1-4 }\end{array}$ & + & + & $+{ }^{1}$ (Macaques) & - & $+(\mathrm{SL})$ & + \\
\hline Chikungunya & + & + & $?$ & - & $+(\mathrm{SL})$ & - \\
\hline $\begin{array}{l}\text { California } \\
\text { encephalitis } \\
\text { serogroup }\end{array}$ & - & $+^{1}$ & $+^{1}$ & - & + & + \\
\hline Chandipura & - & $+{ }^{1}$ & $+{ }^{1}$ & - & + & + \\
\hline $\begin{array}{l}\text { Nairobi sheep } \\
\text { disease }\end{array}$ & - & $+{ }^{1}$ & $+{ }^{1}$ & $+{ }^{1}$ & + & $+/-$ \\
\hline Bhanja & - & $+{ }^{1}$ & + & - & + & + \\
\hline Getah & - & $+{ }^{1}$ & $+{ }^{1}$ & $+{ }^{1}$ & - & - \\
\hline Batai & - & $+{ }^{1}$ & + & $+{ }^{1}$ & $?$ & - \\
\hline Arkonam & - & - & - & $+{ }^{1}$ & - & - \\
\hline Sathuperi & - & $+{ }^{1}$ & $+{ }^{1}$ & - & - & - \\
\hline Wanowrie & $+^{2}$ & - & - & - & + & + \\
\hline
\end{tabular}

California serogroup viruses have been reported to circulate in Azerbaijan and Tajikistan in Central Asia (Lvov et al., 1980) and human infection documented in Shanghai ( $\mathrm{Gu}$ et al., 1984). Since these viruses are well established causes of human encephalitis in North America and febrile disease in Europe (Mertz, 2002), it is important that their role in undiagnosed viral encephalitis in Sri Lanka is investigated.

\section{Chandipura virus}

Chandipura virus is a Vesiculovirus in the family Rhabdoviridae, typically transmitted by Phlebotomus sand flies. Seroprevalence of Chandipura virus was consistently found to be highest in the Mahaweli System C areas, whether in cattle, pigs or humans (Table 5). Three of 80 individuals recently settled in the Mahaweli System C area seroconverted to the virus in their first year of residence (Arunagiri, 1990). Cattle had the highest sero-prevalence of antibodies to Chandipura virus with seroprevalence as high as $94 \%$ in the Dry Zone Mahaweli System C areas but virus activity being present even at higher altitudes of $>3000$ ft. Pig seroprevalence was $42 \%$ in the Mahaweli System C area and lower at high altitudes. At the time these studies were carried out, the clinical importance of Chandipura virus was less well appreciated but it has more recently been incriminated as a cause of epidemic encephalitis in Andhra Pradesh, India, with some outbreaks affecting over 300 children (Rao et al., 2004). The disease starts as an influenza like illness, associated with abdominal pain, vomiting and altered consciousness and impaired neurologic function. Chandipura virus should be particularly investigated for in patients with viral encephalitis or encephalopathy in the Dry zone areas of Sri Lanka.

\section{CONCLUSION}

The arboviruses documented in Sri Lanka in our studies as well as by others are summarized in Table 6. Arbovirus infections remain the archetypal ecological disease where an integrated effort of those involved in public health, entomology, animal health, agriculture and wildlife needs to be harnessed. The late Prashantha Amerasinghe was an excellent example of one who could bridge these intersectoral divides and we remain indebted to him for playing a key role in these studies, among 
many other research studies he carried out during an exceptionally productive scientific career. The need for such an inter-sectoral approach is highlighted also in more recent emerging infectious disease problems such as avian influenza, Nipah and SARS.

\section{ACKNOWLEDGEMENTS}

In addition to the pivotal role of the late Prashantha Amerasinghe in initiating and sustaining this work, it is relevant to acknowledge Dr. P.H. Amerasinghe, Prof. M. de S. Wijesundera, Dr. Thilak Abeysekera (Consultant Physician, Anuradhapura General Hospital during the period of study), Dr. Nihal Abeysinghe (Epidemiologist, Department of Health), Mr. S.B. Abyekoon, Mr. K.G. Abeyratne and $\mathrm{Mr}$. N. Karunaratne of the Department of Microbiology, Faculty of Medicine, University of Peradeniya.

These studies were funded by research grants from the Board of Science and Technology for International Development (BOSTID), the US National Academy of Sciences, by way of a grant from US AID and The Wellcome Trust, UK.

\section{REFERENCES}

Amerasinghe, F.P. and Munasinghe, N.B. (1988). A pre-development mosquito survey in the Mahaweli Development project area, Sri Lanka. adults. J. Med. Entomol. 25: 276-285.

Amerasinghe, F.P. and Ariyasena, T.G. (1991). Survey of adult mosquitoes (Diptera: Culicidae) during irrigation development in the Mahaweli Project, Sri Lanka. J. Med. Entomol. 28: 387393.

Amerasinghe, F.P. and Indrajith, N.G. (1994). Post irrigation breeding patterns of surface water mosquitoes in the Mahaweli Project, Sri Lanka, and comparisons with preceding developmental phases. J. Med. Entomol. 31: 516-523.

Arunagiri, C.K. (1990). Epidemiology of Arboviruses in Sri Lanka. Ph.D. Thesis. University of Peradeniya, Sri Lanka.

Arunagiri, C.K., Perera L.P., Abeykoon, S.B. and Peiris, J.S.M. (1991). A serologic study of California serogroup bunyaviruses in Sri Lanka. Am. J. Trop. Med. Hyg. 45: 377-382.
Bárdos, V., Sixl, W.,Wisidagama, C.L., Halouzka J., Stünzner, D., Hubálek, Z. and Withalm H. (1983). Prevalence of arbovirus antibodies in sera of animals in Sri Lanka. Bull. World Health Organ. 61: 987-990.

Chen, W.R., Tesh R.B. and Rico-Hesse, R. (1990). Genetic variation of Japanese encephalitis virus in nature. J. Gen. Virol. 71: 2915-2922.

Dandawate, C.N. and Shope, R.E. (1975). Studies on physicochemical and biological properties of two ungrouped arboviruses: Minnal and Arkonam. Indian J. Med .Res.63: 1180-1187

De Silva, A.M., Dittus, W.P.J. and Amerasinghe, P.H. (1999). Serologic evidence for an epizootic dengue virus infecting toque macaques (Macaca sinica) at Polonnaruwa, Sri Lanka. Am. J. Trop. Med. Hyg . 60: 300-306.

Ghalsasi, G.R., Rodrigues, F.M., Dandawate, C.N., Gupta, N.P., Khasnis, C.G., Pinto, B.D. and George S. (1981). Investigation of febrile illness in exotic and cross-bred sheep from Sheep Farm, Palamner in Andhra Pradesh. Indian J. Med. Res. 74: 325-331.

Gu, H.X., Spence L., Artsob, H., Chia W.K., Th'ng, C. and Lampotang, V. (1984). Serological evidence of infection with California serogroup viruses (Family Bunyaviridae) in residents of Long Hua, suburb of Shanghai, People's Republic of China. Trans. R. Soc. Trop. Med .Hyg. 78: 780-781.

Hermon, Y.E. (1967). Virological investigations of Arbovirus infections in Ceylon, with special reference to the recent Chikungunya fever epidemic. Ceylon Med. J. 12: 81-92.

Hermon, Y.E. and Anandarajah M. (1974). Isolation of Japanese encephalitis virus from the serum of a child in Ceylon. Ceylon Med. J. 19: 93-99.

Lvov, D.K. (1980). Arboviruses in the USSR. In. Vesenjak-Hirjan J, Arslanagic E, Porterfield JS (Eds) Arboviruses in the Mediterranean Countries. Stuttgart: Gustav Fischer Verlag, Pp. 35-47.

Mackenzie, J.S., Johansen, C.A. and Ritchie, S.A. (2002). Japanese encephalitis as an emerging virus: The emergence and spread of Japanese encephalitis virus in Australasia. 
Current topics in Microbiology and immunology 267: 49-73.

Maheswaran K., Mendis N.M., Hermon Y.E. and De La Motte, .PU. (1976). Serological survey of arbovirus infection in Sri Lanka. Ceylon Med. J. 21: 105-109.

Mertz, G.J. (2002). Bunyaviridae: Bunyaviruses, Nairoviruses and Hantaviruses. In. DD Richman, RJ Whitley, FG Hayden (Eds). Clinical Virology. $2^{\text {nd }}$ Ed. ASM Press. Washinton DC.

Messer, W.B., Vitarana, U.T., Sivananthan, K. (2002). Epidemiology of dengue in Sri Lanka before and after the emergence of epidemic dengue hemorrhagic fever. Am. J. Trop. Med. Hyg. 66: 765-773.

Pavri, K.M., Anandarajah, M., Hermon, Y.E., Nayar, M., Wikramsinghe, M.R. and Dandawate, C.N. (1976) Isolation of Wanowrie virus from brain of a fatal human case from Sri Lanka. Indian J. Med. Res. 64: 557-561.

Peiris, J.S., Amerasinghe, F.P., Amerasinghe, P.H., Ratnayake, C.B., Karunaratne, S.H. and Tsai, T.F. (1992) Japanese encephalitis in Sri Lanka: the study of an epidemic: vector incrimination, porcine infection and human disease. Trans R. Soc. Trop. Med. Hyg. 86: $307-$ 313.

Peiris, J.S., Amerasinghe, F.P., Arunagiri, C.K., Perera, L.P. Karunaratne, S.H, Ratnayake, C.B., Kulatilaka T.A. and Abeysinghe M.R. (1993a) Japanese encephalitis in Sri Lanka: comparison of vector and virus ecology in different agroclimatic areas. Trans. R. Soc. Trop. Med. Hyg. 87: 541-548.

Peiris, J.S., Dittus, W.P. and Ratnayake, C.B. (1993b). Seroepidemiology of dengue and other arboviruses in a natural population of toque macaques (Macaca sinica) at Polonnaruwa, Sri Lanka. J. Med. Primatol. 22: 240-245.

Peiris, J.S., Amerasinghe, P.H., Amerasinghe, F.P., Calisher, C.H., Perera, L.P., Arunagiri, C.K., Munasingha, N.B. and Karunaratne S.H. (1994). Viruses isolated from mosquitoes collected in Sri Lanka. Am. J. Trop. Med. Hyg. 51: 154-161.

Peiris, J.S.M. (1996). Ëpidemiology of arbovirus infections of the central nervous system (CNS) in Sri Lanka. In M. de S. Wijesundera, J.S. Edirisinghe, U.Samarajeewa (Eds). The Concept of a University: Sarath Nanda Arseculeratne Festschrift. Faculty of Medicine, Peradeniya. Pp 21-27.

Perera, L.P.(1986). Survey of mosquito borne arboviruses in an urbanized environment and an area under agricultural development. M. Phil. Thesis. University of Peradeniya.

Perera, L.P., Peiris J.S.M. and Weilgama D.J. (1996). Nairobi sheep disease virus isolated from Haemaphysalis intermedia ticks collected in Sri Lanka. Annals Trop. Med. Parastiol. 90: 91-93.

Powers, A.M. and Logue C.H. (2007). Changing patterns of chikungunya virus: re-emergence of a zoonotic arbovirus .J.Gen. Virol.. 88: 23632377.

Rao, B.L., Basu, A., Wairagkar, N.S., Gore, M.M., Arankalle, V.A., Thakare, J.P., Jadi, R.S., Rao K.A. and Mishra A.C. (2004). A large outbreak of acute encephalitis with high fatality rate in children in Andhra Pradesh, India, in 2003, associated with Chandipura virus. Lancet 364: 869-874.

Vesenjak-Hirjan, J., Hermon, Y. and Vitarana, T. (1969) .Arbovirus infections in Ceylon. Bull. World Health Organ. 41: 243-249. 